\title{
NIDIFICACIÓN SIMULTÁNEA DE SIETE ESPECIES DE AVES (PASSERIFORMES) EN UN BOSQUE DEL CENTRO DE LA PROVINCIA DE SANTA FE
}

\author{
De la Peña, M. R. ${ }^{1}$
}

\begin{abstract}
RESUMEN
En un bosque del centro de la provincia de Santa Fe ( $\left.31^{\circ} 25^{\prime} \mathrm{S}, 60^{\circ} 56^{\prime} \mathrm{O}\right)$, se realizó el relevamiento de los nidos activos (nidificación simultánea) de 7 especies de aves, Furmarius rufus, Phacellodomus sibilatrix, Phacellodomus ruber, Pitangus sulphuratus, Polioptila dumicola, Paroaria coronata y Sicalis flaveola, durante los años 1998 y 2002. Se estudió el periodo reproductivo de cada ave, las especies vegetales que actuaron como soportes de sus nidos, la densidad de nidos por hectárea y la altura, sobre el suelo, en el que se hallaron los nidos.
\end{abstract}

Palabras clave: aves, nidos, reproducción, Esperanza, Santa Fe.

\section{SUMMARY}

\section{Simultaneous nidification of seven birds species (Passeriformes) in a forest of central Santa Fe province.}

Survey of active nests (simultaneous nidification) of 7 bird species, Furnarius rufus, Phacellodomus sibilatrix, Phacellodomus ruber, Pitangus sulphuratus, Polioptila dumicola, Paroaria coronata and Sicalis flaveola, was carried out in a woodland located in the middle of Santa Fe province during the years 1998 and 2002. The breeding period of each species, the vegetation used as nest support, the nest density by hectary, and the nest height from the ground were investigated.

Key words: birds, nest, reproduction, Esperanza, Santa Fe.

\footnotetext{
1.- Martín Rodolfo de la Peña. Médico Veterinario. Académico Correspondiente de la Academia de Agronomía y Veterinaria. 3 de Febrero 1870. (3080) Esperanza, provincia de Santa Fe.

E-mail: martin@fca.unl.edu.ar
}

Manuscrito recibido el 22 de agosto de 2003 y aceptado para su publicación el 21 de noviembre de 2003. 